\title{
RESEARCH AREAS IN THE DEVELOPMENT OF EDUCATIONAL MANAGEMENT
}

\author{
Manap Somantri®s, \\ 'Master of Education Administration, University of Bengkulu, Indonesia \\ $\bowtie$ msomantri@yahoo.com
}

\begin{abstract}
The objectives of this study are elaboration research areas in the development of educational management at the teacher and educational science faculty. Elaboration of research areas significant for the development of competitiveness study program, and can be references candidates for the topic choices of thesis and dissertation or lecturer research at the teacher and educational science faculty. The study will be done to literature analysis on educational management as a dimension process and substances in education. As a dimension, process management has explored while on planning, organizing, staffing, directing, budgeting, controlling, evaluating, and reporting. Substantial management included the curriculum, student, teacher, staff, money, facilities, and participation in educational management. The organization level can be analyses on global, regional, local, and institutional levels. The organizational function can be analyses on leadership, planning, supervision, communication, decision making, and innovation in the management process. The area's research in educational management has used for institutional innovation and student achievement.
\end{abstract}

Keywords: Research areas, Educational management development

INTRODUCTION Academic This paper elaborates on the map of the area of research and development in education management in the educational administration master program. The elaboration of the map of the research and development management education area is essential to be carried out by the educational administration master's study program because most students still have difficulty in determining the topic and problem formulation for research in the context of a thesis, dissertation, or research development conducted by lecturers in the field of administration /education Management. Most (8 out of 10) students have difficulty in formulating research problems, (2) difficulty in determining the relationship between a research variable with other variables; and (3) many students have lost their way in preparing their thesis and dissertation, and (4) the lack of references for research and development conducted by students and lecturers in the education administration study program, the lack of references.

Difficulties of students are highly valuing in sorting out anything related to policies, management processes, and quality of education. The study has carried out through educational management library research, and both viewed from the dimensions of the management process, the substance being managing, and the functions that affect the performance of the management team. Research and development in education management has conducted at the level (national, regional (provincial), local (district/city), or institutional (educational unit) ("Educ. Leadersh. Manag. Theory, policy, Pract.," 2007), (Little, 1993) ("Educ. Leadersh. Manag. Theory, policy, Pract.," 2007).

In terms of organizational functions, it needs to be examining in terms of 
leadership, communication, individual, group behavior, decision making, coaching, coordination, problem-solving, and educational management innovation. The map of the area of research and development in education management has used as material for academic strengthening in the education administration master program.

The ability to elaborate maps in the area of management education research plays a crucial role. Because success in developing study programs and their influence in the fields of work that are relevant to the outputs of study programs, as well as can be used as a chat tool in formulating research titles and program development, both in thesis framework, dissertation, as well as research and development conducted by lecturers and students. More than that, the principal must be able to adapt and adapt to global developments, national policies, regional policies, and local policies in the administration of education in schools. Therein lies the need to map the research area in the field of

\section{METHODS}

The writing method used in this study is the elaboration of fishbone analysis related to (1) education management policy studies; (2) education management processes; (3) the substance of education that needs to be managing; and (4) leadership and organizational behavior, both at the institutional, local, regional, national and international levels.

\section{DISCUSSION}

Map of Study Area Research Program

Masters in Educational Administration

A. Education Management Policy Studies education management. (Heyer, Weber, Rose, Perkins, \& Schmittaver, 2015).

The general objectives of this study are to elaborate: (1) a map of the education management policy in research area; (2) maps had reviewed from the education management process; (3) map of the research area in terms of the substance of education that has managed; and (4) leadership and behavior of educational organizations at the education unit level, local, regional, national and international.

The scope of the elaborated material includes (1) map of education management policy studies; (2) map of the research area of the education management process; (3) maps of the area of educational substance that has managed; and (4) leadership and organizational behavior. A map of the area of research and development in education management has used as material for academic strengthening in the educational administration master program ("Educ. Leadersh. Manag. Theory, policy, Pract.," 2007)

\section{(National / Regional / Institutional)}

1. Regulations on education: (Law, Permen, Perda, Pergub, Perbup / Perwali)

2. Implementation Instructions: AD, ART, SOP, Organizational Governance / Education Unit

3. Technical Instructions (Work Procedures) of each organizational unit / Service Unit)

4. Research on the implementation of educational policies (Jordan \& Tosun, 2012)

5. Reviewing educational policies and linkages 


\section{B. Research Areas About the Process of Education Management}

1. Educational Planning
a. Educational planning (Renstra, RPJ- /Operational / Annual Plans) Length, RPJ-Medium, RPJ-Short
b. Strategic Plan (Vision, Mission, Objectives, Education Management Strategy)
c. Medium-term Plan (Development Plan, Period Development Plan)
d. Operational Plan (Annual Cycle, Semester, Tri-Month, Monthly, Weekly)
e. Monitoring and Evaluation of Education Policy Implementation. (Somantri, 2014)

2. Organizing Research Areas
a. Organizational forms and rules
b. Organizational structure and Position Mapping
c. Job Analysis
d. Filling out positions
e. Control range
f. Organizational Effectiveness (Borko, 2004)

3. Staff Charging
a. Employee selection
b. Employee mutation
c. Employee upgrading and rotation

4. Employee direction
a. Socialization of the organization's vision, mission, goals
b. Motivating \& Coaching
c. Full implementation and main duty

5. Control (Monitoring \& Monitoring)
a. Structural supervision
b. Control range
C. Instrument of control

6. Budgeting \& Financing
a. Revenue budget plan
b. Income payment mechanism
C. Allocation of distribution and disbursement of costs
d. Budgeting guidelines
e. Taxation
f. E-budgeting
g. Liability

7. Reporting
a. Routine activity reports (daily, weekly, monthly, quarterly, midyear, and yearly)
b. Special activity report
c. Performance report
d. Accountability Report

\section{Research Areas About the Substance of Education}

1. Curriculum Management \& Learning
a. Curriculum development (curriculum legality (Mohanasundaram, 2018)
b. Curriculum documenters (Doctor-1, Doctor-2, Doctor-3, Doctor-4)
c. Implementation of curriculum \& learning
d. Monitoring and evaluating curriculum implementation (Little, 1993)

e. The relevance of curriculum (graduate competencies with employment)

f. external feedback from alumni of study administration master program in education administration

g. Curriculum review

2. Learning management research Management of Education Facilities and Prasarana 
a. Analysis of education sarpras needs

b. Profile of education sarpras

C. C. Analysis of strengths/weaknesses of sarpras

d. d. Sarpras procurement (add/buy items that are less / needed)

e. e. Sarpras quality improvement through (rehab, maintenance, repair, replacement) (Johnson, 2009)

f. Utilization of sarpras (effectiveness \& efficiency of the use of sarpras)

g. Sarpras control and documentation

h. Destruction of education sarpras

i. Sarpras monitoring and evaluation

3. Management of Educators and Educational Personnel

a. Analysis of the needs and organization of educators and education personnel

b. Conditions/profiles of educators and education personnel

c. Analysis of the strengths/weaknesses of educators and education personnel

d. Recruitment, appointment, and placement of educators and staff.

e. Direction and guidance of educators and education staff

f. Performance appraisal of educators and education personnel

g. Guidance of educators and education staff (supervision, education and training, comparative studies, and the like)

h. Giving rewards and punishment, mutations, promotion of educators and education staff

i. Dismissal of educators and education personnel
4. Management of Students (Bossert, Dwyer, Rowan, \& Lee, 1982)

a. Capacity, promotion, and acceptance of new students \& transfers

b. Placement/grouping of students

c. Education, training, guidance, development of talents, interests, and potential of students

d. Special services (services of students with positive and negative special needs)

e. Development of student databases (starting in students leaving school) and alumni

f. Student management innovation, cohort analysis, and compulsory education completion strategies.

g. Graduate control.

5. Management of Education Funding . Design the cost of education (semester, year, and four years)

a. Management of educational funding sources

b. Allocation of education funding

c. utilization of education funding

d. Accountability for education funding

e. Accountability for education funding

f. Tax variables in education funding

D. Concept Map of Leadership and Organizational Behavior

1. Concept of Leadership

a. The process of establishing leaders

b. Leadership styles ("Educ. Leadersh. Manag. Theory, policy, Pract.," 2007)

c. Leadership Effectiveness

d. Philosophy and leadership theory

e. Leadership influence 
f. Relationship between leader and leader

2. Concept of Organization
a. Definition, type, and organizational structure
b. Organization goals
c. The scope of the organization
d. Organizational climate
e. Organizational Development

3. Leadership Functions ("Educ. Leadersh. Manag. Theory, policy, Pract.," 2007)
a. Decision-making
b. Communication
c. Motivation (Bush, 2006)
d. Supervision / Coaching
e. Managerial
f. Supervision

4. Academic Supervision

Development of managerial supervision instruments

a. Design and completeness of managerial supervision laboratory equipment

b. Test the effectiveness of the instrument, analysis, and follow-up plan for the findings.

5. Managerial Supervision

C. Various managerial supervision techniques and approaches as well as implementation and evaluation of their effectiveness;

d. Development of managerial supervision instruments;

e. The completeness of the managerial supervision laboratory;

f. Test the effectiveness of the instrument, analysis, and follow-up plan for the findings.

g. Various managerial supervision techniques and approaches as well as implementation and evaluation of their effectiveness;

h. Monitoring, evaluation, research and measurement of education

i. Reporting (Monthly, Quarterly, Wulan Chess, Semester, Annual, quarterly).

j. Development of monitoring instrumentation, evaluation, research, and educational measurement. (Bossert et al., 1982)

\section{CONCLUSIONS AND SUGGESTIONS}

\section{Conclusions}

Maps of educational management research areas have been using as a reference for students and lecturers in determining topics and developing a thesis, dissertation, and research and development conducted by lecturers. The study is conducting through a search of educational management literature, both viewed from the dimensions of education management policies, educational management processes, educational substance, and leadership and organizational behavior, both at the level (national, provincial, district/city, or education unit). In terms of leadership and organizational behavior, the concepts of leadership, organization, and organizational behavior have been reviewing.

\section{Suggestions}

The map of the research area should be presented transparently and be a reference for students, lecturers, and study programs in the context of controlling research products, and their use for educational management practices in the field or the improvement of theories and studies on education management. Students can use the map 
of the research area to promote their research thesis or dissertation compared with existing research. Likewise, for lecturers, they can use a map of the area to examine what has not been studied and need to get more careful attention in subsequent studies. As for the study program, it has used to provide direction for lecturers and students in preparing their next research proposal and report.

\section{REFERENCES}

Borko, H. (2004). Professional Development and Teacher Learning: Mapping the Terrain. Educational Researcher, Vol. 33, pp. 315.https://doi.org/10.3102/0013 189X033008003

Bossert, S. T., Dwyer, D. C., Rowan, B., \& Lee, G. V. (1982). The Instructional Management Role of the Principal. Educational Administration Quarterly. https://doi.org/10.1177/001316 1X82018003004

Bush, T. (2006). Theories of Educational Management. International Journal of Educational Leadership Preparation.

Educational leadership and management: theory, policy, and practice. (2007). Educational Leadership and Management: Theory, Policy, and Practice.

Heyer, G. L., Weber, K. D., Rose, S. C., Perkins, S. Q., \& Schmittauer, C. E. (2015). High school principals' resources, knowledge, and practices regarding the returning student with a concussion. Journal of Pediatrics. https://doi.org/10.1016/j.jpeds. 2014.09.038

Johnson, S. L. (2009). Improving the school environment to reduce school violence: A review of the literature. Journal of School Health. https://doi.org/10.1111/j.17461561.2009.00435.x

Jordan, A., \& Tosun, J. (2012). Policy implementation. In Environmental Policy in the EU: Actors, Institutions and Processes, Third Edition. https://doi.org/10.4324/978020 3109823

Little, J. W. (1993). Teachers' Professional Development in a Climate of Educational Reform. Educational Evaluation and Policy Analysis. https://doi.org/10.3102/016237 37015002129

McLaughlin, M. W. (1987). Learning From Experience: Lessons From Policy Implementation. Educational Evaluation and Policy Analysis. https://doi.org/10.3102/016237 37009002171

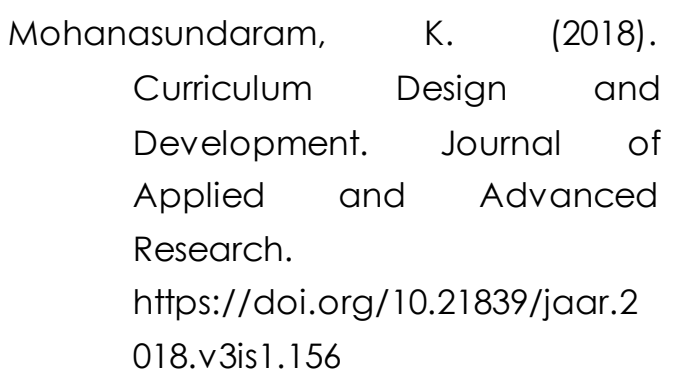

Somantri, M. (2014). PERENCANAAN 
PENDIDIKAN (Pertama;

Kurniawan Cahadiyat, Ed.). Bengkulu: IPB Press.

Borko, H. (2004). Professional Development and Teacher Learning: Mapping the Terrain. Educational Researcher, Vol. 33, pp. 3-15. https://doi.org/10.3102/001318 9x033008003

Bossert, S. T., Dwyer, D. C., Rowan, B., \& Lee, G. V. (1982). The Instructional Management Role of the Principal. Educational Administration Quarterly. https://doi.org/10.1177/001316 1X82018003004

Bush, T. (2006). Theories of Educational Management. International Journal of Educational Leadership Preparation.

Educational leadership and management: theory, policy, and practice. (2007). Educational Leadership and Management: Theory, Policy, and Practice.

Heyer, G. L., Weber, K. D., Rose, S. C., Perkins, S. Q., \& Schmittauer, C. E. (2015). High school principals' resources, knowledge, and practices regarding the returning student with a concussion. Journal of Pediatrics. https://doi.org/10.1016/j.jpeds. 2014.09.038

Johnson, S. L. (2009). Improving the school environment to reduce school violence: A review of the literature. Journal of School
Health.

https://doi.org/10.1111/j.1746-

1561.2009.00435.x

Jordan, A., \& Tosun, J. (2012). Policy implementation.

In

Environmental Policy in the EU:

Actors, Institutions and

Processes, Third Edition. https://doi.org/10.4324/978020

3109823

Little, J. W. (1993). Teachers' Professional Development in a Climate of Educational Reform. Educational Evaluation and Policy=Analysis.https://doi.org/ 10.3102/01623737015002129

McLaughlin, M. W. (1987). Learning From Experience: Lessons From Policy Implementation. Educational Evaluation and Policy Analysis. https://doi.org/10.3102/016237 $\underline{37009} 02171$

Mohanasundaram, K. (2018).

Curriculum Design and Development. Journal of Applied and Advanced Research.

https://doi.org/10.21839/jaar.2

018.v3is 1.156

Somantri, M. (2014). PERENCANAAN PENDIDIKAN (Pertama; Kurniawan Cahadiyat, Ed.). Bengkulu: IPB Press. 